\title{
THE EFFECT OF MONOLAURIN ON THE COLOUR AND MICROBIOLOGICAL SAFETY OF NITRITE REDUCED SAUSAGES
}

Irina Mladenoska*, Misela Temkov, Darko Dimitrovski

Department of Food Technology and Biotechnology, Faculty of Technology and Metallurgy, University of „Ss. Cyril and Methodius“ Skopje, Macedonia

The aim of this work was to investigate the possibility for the development of new meat cured products with a decreased nitrite content, but unchanged sensory characteristics and prolonged shelf life. Thus, the possibility to replace or to decrease the amount of the nitrite salt by including other non-toxic additive in the product making process was investigated. The effects of different recipes on both sensory characteristics and microbiological safety of the meat products were evaluated. The results showed that even with a very low concentration of nitrite salt, but in presence of monolaurin, the desired pink nuance of the meat batter could be achieved. When half of the amount of nitrite salt $(0.2 \%)$ was replaced with $0.72 \%$ of monolaurin, the meat product, collagen packed sausage with both good sensory properties and microbiological safety was produced. Thus prepared product showed the 21 times lower value for the total cell count of the bacterium Bacillus subtilis D-TMF compared to the product with only nitrite salt as a food additive.
(ORIGINAL SCIENTIFIC PAPER) UDC 637.523.05:664.9

Keywords: cured meat products, decreased nitrite amount, food additives, monolaurin

\section{Introduction}

Nitrites and nitrates are one of the most frequently used food preservatives and conventional food additives in cured meat products [1]. Thus, in the cured sausage production process those compounds are used for several reasons: they inhibit the growth of undesirable pathogens, in the first place the dangerous neurotoxin Clostridium botulinum strain, and they give the product the desired red colour typical for cured meat products. According to the US Environmental Protection Agency (US EPA) report on the toxicity and exposure assessment of nitrates and nitrites, the exposure to nitrates and nitrites at the levels above health-based risk values has been reported to have adverse health effects on infants and children [2]. It is also known that nitrites and nitrates are precursors of the potentially carcinogenic $\mathrm{N}$-nitroso compounds, such as nitrosamines that can be formed in the human digestive tract after the consumption of food containing those additives [3]. The need for alternatives in the meat curing process, in order to produce nitrite free cured meat products and to label the meat production as natural or organic has already been well elaborated and the new technology of "alternative curing“ was developed by indirect addition of vegetable source of nitrites $[4,5]$. The application of natural antimicrobials instead of the conventional ones might enable the reduction of some potentially toxic conventional food additives and antimicrobials such as nitrites and nitrates [6]. Nowadays, natural antimicrobials such as essential oils of cinnamon and cloves [7] extracts of garlic [8], neem [9] and other spices, oleoresins, fatty acids and their esters or chitosans are widely used in different food products in order to not only establish a safe food preservation process, but also to give the product a new quality and the added value. A search for novel preservation techniques, such as the non-thermal preservation technology [10] together with the modified atmosphere packaging [11] is still going on. The new preservation techniques should enable guarantied microbiological safety while preserving all biological active compounds [12]. In the case of meat products, food safety is especially important since the bacterial contamination is the most probable and the most dangerous one and might be a result of the contamination of raw material or the secondary contamination of the ready-to-eat meat product [13]. The monolaurin is a natural antimicrobial agent found in breast milk, coconut oil and in the Serenoa repens plant [14]. It belongs to partial glycerides of medium-chain fatty acids and the antimicrobial activity of these substances is well examined in vitro. Thus, the antimicrobial activity of both monolaurin and monocaprilin on several bacterial, fungal and yeast strains were examined by Ružička et al., [15], while Rihakova et al., [16] evaluated the antifungal activity of monoglycerides synthesized from the coconut oil and Skrivanova et al., [17] investigated the effect of some organic acids and monolaurin on bacteria E. coli, Salmonella sp. and Clostridium perfrigens. Known for its positive effect on the human immune system, monolaurin has been applied in various food products such as infant formulas [18], meat products [13] and other products where this food additive has shown its pronounced antimicrobial activity. Kabara and Marshall,

\footnotetext{
* Author address: Irina Mladenoska, Department of Food Technology and Biotechnology, Faculty of Technology and Metallurgy, University of „Ss. Cyril and Methodius“, Rudjer Boskovic 16, 1000, Skopje, Macedonia

E-mail: irinaetf@t.mk

The manuscript received: December, 16, 2016.

Paper accepted: April,3, 2017.
} 
[14] are pointing out the antimicrobial activity of monolaurin and suggesting that this antimicrobial should be included in the daily food supplement uptake, since it has proven a positive effect on the human immune system.

In this work, several new kinds of model meat products were prepared containing decreased amounts of nitrite salts and monolaurin. The antibacterial activity of monolaurin and other additives integrated in the model meat sausages was evaluated by using Bacillus subtilis D-TMF as an infecting bacterium. The minimal bactericidal concentration of monolaurin was also determined. The colour parameters $L^{*}, a^{*}, b^{*}$ and total changes of the colour $\Delta E$ of uncured and cured sausages were also measured, and the effect of different additives on the product colour were quantitatively determined.

The aim of the work was to investigate if monolaurin could be a substitute for nitrites and nitrates, to guarantee the safety of sausages and attractive sensory properties at the same time.

\section{Experimental}

\section{Material}

Monolaurin which was used in the experiment was in a form of capsules containing powder with $99 \%$ of purity produced by „Ecological formulas“, Concord, California, the USA.

The Nutrient broth No 1 (Sigma-Aldrich, Buchs, Switzerland) was used for the preparation of the agar media.

The test microorganism, the microbial strain Bacillus subtilis D-TMF was isolated from the probiotic drug "Diastop“, Alkaloid, Skopje and deposited at the Culture Collection of the Faculty of Technology and Metallurgy in Skopje, the Republic of Macedonia. Fresh minced meat was bought from the local food store.

\section{Methods}

Preparation of meat batters and sausages

Meat batters containing different additives, separately or in their combination, were prepared according to the previously described procedure [3]. Different kinds of additives were added to the minced meat batter and the batter was filled in different casings. The sausages were then precooked by the process of pasteurisation $\left(72^{\circ} \mathrm{C}\right)$ in the centre of the sausage in duration of $20 \mathrm{~min}$. Meat sausages containing different additives were prepared according to the flow-chart presented in Figure 1 that was slightly modified. The modification is referred mostly to smoking of the sausages (namely the model sausages in this work were not smoked). All the sausages were prepared to have the weight of $25 \mathrm{~g}$. The additives used in the process for the preparation of the sausages stuffed in collagen casings were as follows: 1. Additive free, 2. $0.2 \% \mathrm{NaNO}_{2}, 3$. $1.2 \%$ monolaurin, 4. $0.1 \% \mathrm{NaNO}_{2}$ and $0.72 \%$ monolaurin, 5. $0.2 \% \mathrm{NaNO}_{2}, 0.6 \%$ monolaurin and $2 \% \mathrm{NaCl}$. The sausages stuffed in natural pork casings (small intestine) also contained different additives, alone or in the combination: 1. additive free, 2. $1.2 \% \mathrm{NaNO}_{2}, 3.0 .6 \% \mathrm{NaNO}_{2}$ and $0.36 \%$ monolaurin, 4. 0.72\% monolaurin, 5. 1.44\% monolaurin, 6. $1.2 \% \mathrm{NaNO}_{2}, 0.72 \%$ monolaurin and $1.2 \% \mathrm{NaCl}$. It should be pointed out that during the preparation processes, special care should be taken in the filling phase because proper filling of natural casings appeared to be much more difficult than the filling of collagen casings.

\section{Preparation of the growth medium}

The quantity of $25 \mathrm{~g}$ of the Nutrient broth No 1 powder was dissolved in $1 \mathrm{~L}$ distilled water and $2 \% \mathrm{w} / \mathrm{w}$ agar was added to the solution prepared in this way. The final $\mathrm{pH}$ of the solution was 7.5 at $37^{\circ} \mathrm{C}$. It was sterilized at $121^{\circ} \mathrm{C}$ in duration of $15 \mathrm{~min}$. The test microorganism was grown on the Nutrient broth No 1 prepared as described above.

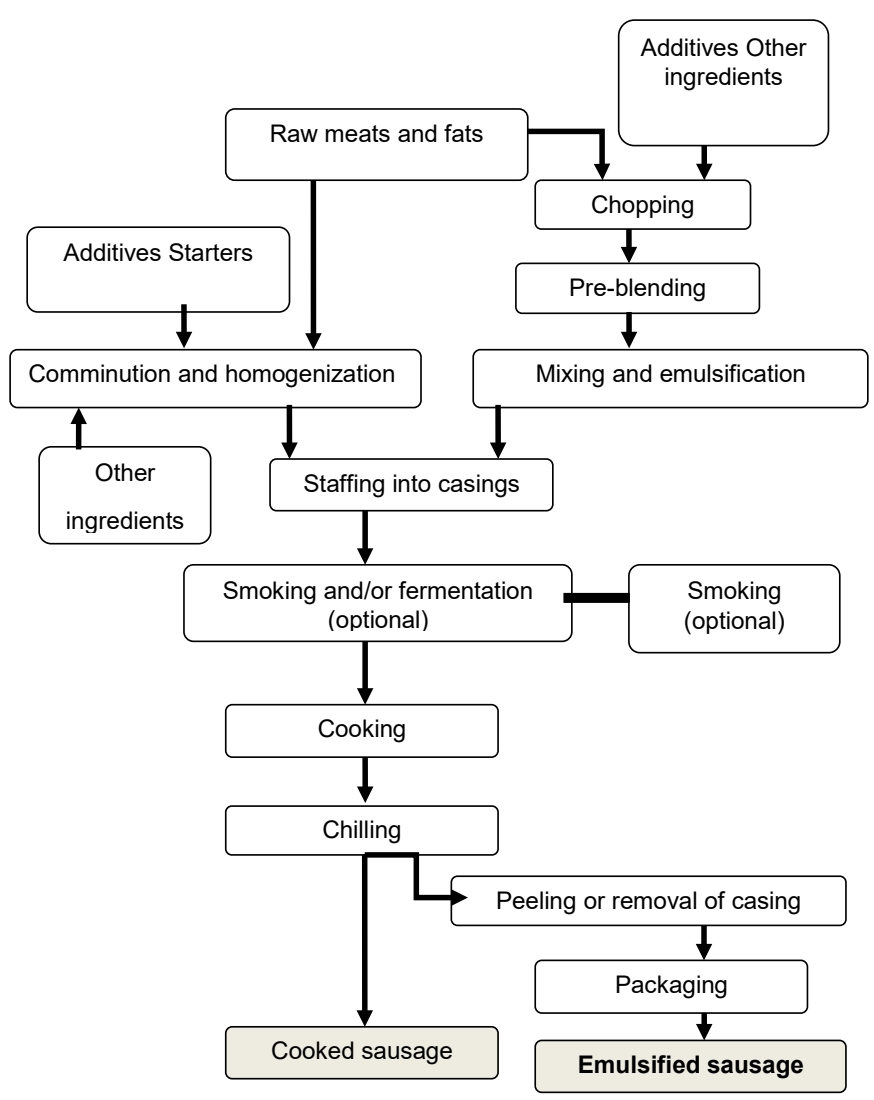

Figure 1. Flow-chart of the process for the industrial production of sausages (Adapted from Toldra and Reig, [3])

\section{Inoculation of the sausages}

Pasteurized sausages were inoculated by $6 \mathrm{~mL}$ cell suspension of Bacillus subtilis D-TMF, with the concentration of $1.25 \times 10^{7} \mathrm{cfu} / \mathrm{mL}$. Thus inoculated sausages were kept $24 \mathrm{~h}$ on $30^{\circ} \mathrm{C}$. Cell enumeration of the sausage samples was performed by standard plate counts and calculated as a number of colony forming units per a gram of the sample. $25 \mathrm{~g}$ of the sample was diluted in $225 \mathrm{~mL}$ of water and homogenized. $1 \mathrm{~mL}$ of this solution was diluted $10^{5}, 10^{6}$ and $10^{7}$ times. $1 \mathrm{~mL}$ of all the three solutions was taken and inoculated on an agar plate containing $12 \mathrm{~mL}$ agar. The agar plates were incubated at $30{ }^{\circ} \mathrm{C}$ for 24 hours. The experiment was performed in triplicate and the mean value of all three measurements was shown in the results. 
Determination of the minimal bactericidal concentration (MBC)

Different amounts of monolaurin that corresponded to the concentrations of $1000,750,500,400,300,200,100$, 50 and $0 \mathrm{mg} / \mathrm{L}$ were added to individual doses of the Nutrient agar, which were then autoclaved at $121{ }^{\circ} \mathrm{C}$ for 35 minutes. After cooling, the solutions were dosed aseptically in $20 \mathrm{~mL}$ quantities into Petri Dishes (150x25 mm). A $1 \mathrm{~mL}$ portion of the cultures having a certain concentration $\left(\approx 10^{7} / \mathrm{mL}\right)$ were dosed onto the surface of the solidified agars enriched with monolaurin. The plates were incubated for 3 days at $30{ }^{\circ} \mathrm{C}$. The MBC values for the $B$. subtilis DTMF culture corresponded to the lowest concentration of monolaurin that completely disabled the growth of the microorganism i.e. no visible growth on the Petri Dishes could be detected.

\section{Colour measurement}

Dr. Lange spectro-colour colorimeter was used to measure the colour of raw and cured sausages with different concentrations of additives. The instrument was calibrated against the black and white tile before use. The samples with added monolaurin, sodium nitrite and sodium chloride were prepared according to Table 1. and placed above the light source. The three parameters, that is, $L^{*}$ (lightness - darkness), a* (greenness - redness), b* (yellowness - blueness) were measured. Data were collected from 15 measurements on each sample. Total colour difference $\Delta \mathrm{E}$ was calculated using the following equation:

$\Delta \mathrm{E}=\left[\left(\Delta \mathrm{L}^{*}\right)^{2+}\left(\Delta \mathrm{a}^{*}\right)^{2+}\left(\Delta \mathrm{b}^{*}\right)^{2}\right]^{1 / 2}$

\section{Results and discussion}

Appearance of meat batter containing different additives The model meat batter was prepared according to the instructions described in the materials and methods section. The appearance of the model meat batter products containing different food additives, before and after the cooking procedure, is presented in Figures 2, 3 and 4.

From the results presented in Figure 2, it can be noticed that even the lowest concentration of nitrite used, $0.1 \%$ (batter No. 2) resulted in the production of the meat product with a desired pink colour, which was most intensive in the batter No. 3 containing $0.2 \% \mathrm{NaNO}_{2}, 0.6 \%$ monolaurin and $2 \% \mathrm{NaCl}$. The typical pink colour of the cured meat cooked product was also visible for the meat batter product No. 4 (fig. 2 , down) containing only $0.2 \%$ nitrite salt as an additive, although the most intensive pink colour was observed in the batter No. 4 , i.e. the batter containing $0.2 \% \mathrm{NaNO}_{2}$, $0.6 \%$ monolaurin and $2 \% \mathrm{NaCl}$. Batter No. 4 had a two times higher concentration of nitrite salt than batter No. 3 .
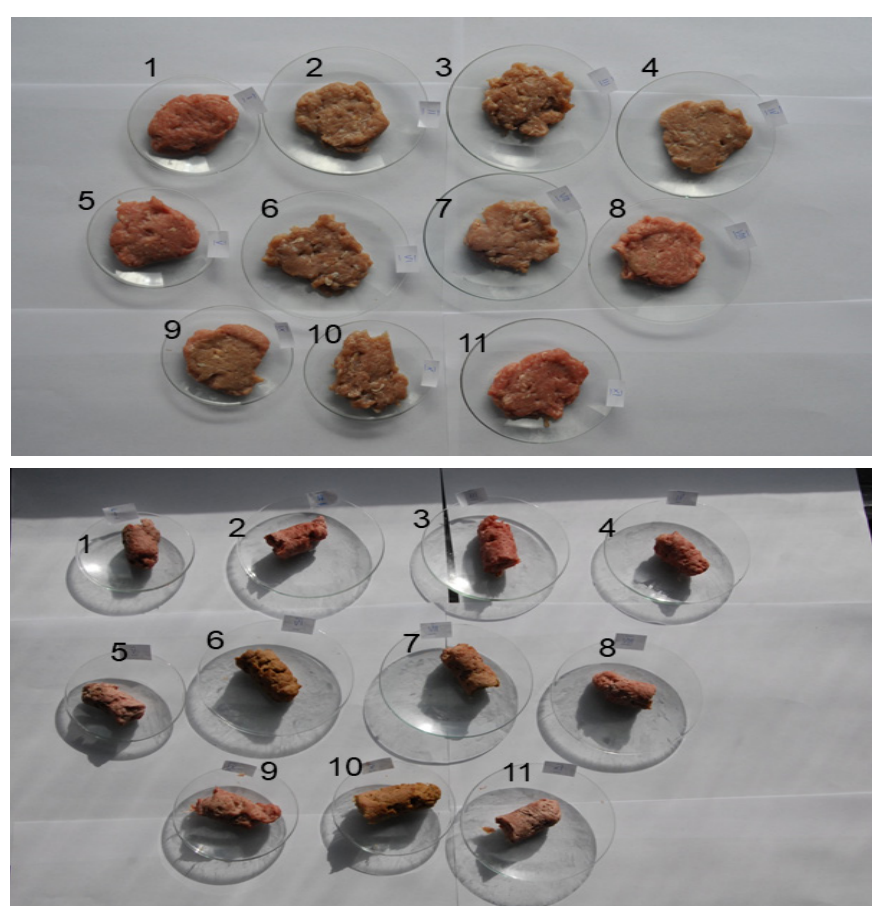

Figure 2. The appearance of the cured model meat batters containing different food additives before (up) and after (down) the cooking procedure. The additives added were as follows: $1.1 .2 \%$ monolaurin; 2. $0.1 \% \mathrm{NaNO}_{2}$ and $0.72 \%$ monolaurin; 3. $0.2 \%$ $\mathrm{NaNO}_{2}, 0.6 \%$ monolaurin and $2 \% \mathrm{NaCl}, 4.0 .2 \% \mathrm{NaNO}_{2}$; 5 . Control (additive free); 6. 1.2\% $\mathrm{NaNO}_{2}$; 7. $0.6 \% \mathrm{NaNO}_{2}$ and $0.36 \%$ monolaurin; 8. 0.72\% monolaurin; 9. 1.44\% monolaurin; $10.1 .2 \%$ NaNO2, $0.72 \%$ monolaurin and $1.2 \% \mathrm{NaCl}$ and $11.1 .2 \% \mathrm{NaCl}$

In Figure 3, the appearance of the meat batters containing different additives and the control one are presented. It was very interesting that very high concentrations of nitrite salt had a negative effect on the products giving undesirable yellow-brown colour instead of pink. This was the case when the nitrite salt was used in the concentration of $1.2 \%$ as a sole additive (product No. 5 on the fig. 3). Here, again, it could be more clearly seen that the product No. 4. containing $0.2 \% \mathrm{NaNO}_{2}, 0.6 \%$ monolaurin and $2 \% \mathrm{NaCl}$ had the most intensive pink colour.

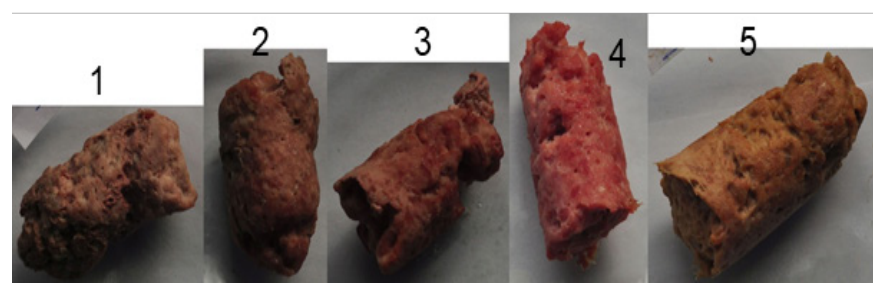

Figure 3. The appearance of the cured model meat batters containing: 1 (control), 2 (1.2\% monolaurin), $3\left(0.1 \% \mathrm{NaNO}_{2}\right.$ and $0.72 \%$ monolaurin), $4\left(0.2 \% \mathrm{NaNO}_{2}, 0.6 \%\right.$ monolaurin and $2 \%$ $\mathrm{NaCl})$ and $5\left(1.2 \% \mathrm{NaNO}_{2}\right)$.

It should also be pointed out that monolaurin gives the acceptable orange-red colour of meat products when used in different concentrations (Fig. 4). 


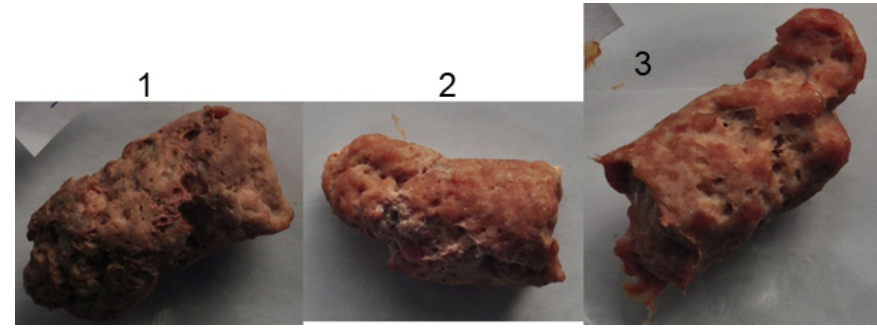

Figure 4. The appearance of the cured model meat batters containing: 1 (control), 2 (0.72\% monolaurin); 3 (1.44\% monolaurin).

Table 1. Safety of the sausages stuffed in collagen and natural casings expressed as a total cell count of the infecting Bacillus subtilis D-TMF strain

\begin{tabular}{|c|c|c|c|c|}
\hline \multirow{2}{*}{$\begin{array}{l}\text { Type of the } \\
\text { sausage }\end{array}$} & \multicolumn{3}{|c|}{ Additives addeda } & \multirow{2}{*}{$\begin{array}{l}\text { Total cell } \\
\text { count }^{b}\end{array}$} \\
\hline & Monolaurin & $\mathrm{NaNO}_{2}$ & Table salt & \\
\hline & - & - & - & $6240 \pm 10$ \\
\hline & - & 0.2 & - & $210 \pm 5$ \\
\hline & 1.2 & - & - & $0.2 \pm 0.05$ \\
\hline & 0.72 & 0.1 & - & $10 \pm 1$ \\
\hline & 0.2 & 0.6 & 2 & $9.5 \pm 1$ \\
\hline & - & - & - & $1500 \pm 10$ \\
\hline & - & 1.2 & - & $400 \pm 5$ \\
\hline & 0.36 & 0.6 & - & $330 \pm 5$ \\
\hline & 0.72 & - & - & $60 \pm 1$ \\
\hline & 1.44 & - & - & $30 \pm 1$ \\
\hline & 0.72 & 1.2 & 1.2 & $110 \pm 5$ \\
\hline
\end{tabular}

$\mathrm{b}$ - number of colony forming units (cfu) calculated as 7 log cfu per $\mathrm{g}$ sample

Safety of sausages containing different additives

Two types of cured meat products, sausages stuffed in collagen casings and sausages stuffed in natural casings were prepared. Those products were containing 3 different compounds as additives: monolaurin, nitrite salt and table salt. In order to evaluate the antimicrobial activity of those additives, the sausages were inoculated by Bacillus subtilis D-TMF strain, after the process of pasteurization and drying. As the contamination level, the total cell count of the bacterium presented as a number of colony forming units (cfu) calculated as 7 log cfu per $\mathrm{g}$ sample was used. The results are presented in Table 1. From the results presented in Table 1, it is obvious that the application of monolaurin as an antimicrobial additive was followed by a sharp drop of the total cell count (TCC) of $B$. subtilis D-TMF in the inoculated sausages. Thus, the value for the TCC was as high as $624 \pm 10 \times 7 \mathrm{log}$ $\mathrm{cfu} / \mathrm{g}$ for the control sausage packed in collagen casings, and dropped at the value of $0.2 \pm 0.05 \times 7 \mathrm{log} \mathrm{cfu} / \mathrm{g}$ for the sausage with $1.2 \%$ monolaurin. It is very interesting to notice that when the conventional nitrite salt, added in the two times lower concentration, was combined with monolaurin added in the concentration of $0.72 \%$, the cell count had the value that was 21 times lower, compared to that measured for the sausage with only nitrite salt, i.e. the sausage No. 2 of the sausages packed in collagen casings. This means that if nitrite salt is added in very low concentrations, but together with monolaurin, both sensory (the colour) and antimicrobial effects are more than acceptable (cooked meat batter No. 3 presented in Fig 2). In this way, both food safety and sensory perspectives for the novel meat products with reduced amounts of nitrite salts are promising.

It was obvious that, as in the case of meat batter products, it is possible to use very low concentrations of nitrite salt in both type of sausages, and to achieve both good sensory characteristics (colour) and safety, but that the nitrite salt cannot be completely replaced with other additives if one insists on having a typical pinkish nuance of the colour, although monolaurin also gives meat products an attractive orange-red colour (Figures 2, 3 and 4).

In the meat industry, the usual nitrite concentration is as low as 200 ppm [1] but the tendency of organic meat producers is to completely replace this additive. Howev$\mathrm{er}$, the main obstacle on the way of the complete removal of nitrites and nitrates from the cured meat product is not the colour but the microbiological safety, primarily the safety against the food-born pathogen bacterium Clostridium botulinum [19]. This bacterium is one of the most toxic anaerobic strains and it has been reported that from 112 confirmed cases of botulism in the USA in the year 2010, 85 belonged to the infant cases, 9 were food-borne caused, 17 were wound caused and others were of undefined cause [20]. The natural purplish-red meat colour comes from the pigment myoglobin. When this pigment comes into contact with the oxygen from the air, a light red colour pigment called oxymyoglobin is formed. These two pigments have the ability to lose electron, yielding to a brown pigment called metmyoglobin. Depending on the meat storage condition, the pigments can change forms from one to another. After cooking, brown colour is formed from irreversibly denaturized metmyoglobin [21]. Curing of meat has been done for many years for preservation, visual appearance, flavor and textural properties. Sodium nitrate/nitrite is the most common salt used in cured products, rubbed in the meat surface or injected in the tissue as a solution. The main reason for adding nitrite or nitrate salts to meat products is their unique protective effect against toxin-forming bacteria such as Clostridium botulinum [22]. The nitrite itself is not bacteriostatic, but the compounds derived from it such as nitric oxide, nitrous acid, peroxynitrite and other nitrosyl compounds are. Their inhibitory effect could be due to binding iron-sulfur protein of bacteria, an important protein of energy metabolism, by influencing the phosphoroclastic system, another important source of ATP in the Clostridia. Nitrites, as well as nitrous acid, could react with thio-proteins from bacterial cells producing nitrosothiols, which on the other hand act as enzyme inhibitors in the growth metabolism. Some of the derivates could inhibit the polymerization of the cell walls, or could alter the permeability of the cell allowing leakage 
of the components or hindering the transport of nutrients into the cell [23]. Here again, it should be mentioned that those same compounds are suspected as possible inducers of some carcinogenic effects of the processed food to the consumers [24]. However, the literature data confirms that monolaurin has proven the antibacterial activity against this bacterium and thus it might completely replace the nitrite salt [14]. The antibacterial activity of monolaurin against the bacterium from Clostridium genera, and against the Staphylococcus, Corinebacterium, Lysteria and Escherichia genera was investigated also in vitro and it was found out that this compound inhibited the growth of the examined bacteria to a great extent [24-26]. However, the research on this issue should be extended.

It was very interesting to see whether the added additives, as sole ingredients or in the combination with other additives in sausages packed in natural casings, showed the same antimicrobial effect against the bacterium $B$. subtilis D-TMF as it was the case with the sausages packed in collagen casings (Table 1). It was noticeable that the increase of the monolaurin concentration from 0.36 to $1.44 \%$ resulted in the increase of its antimicrobial effect for about 10 times. However, the sausages with only monolaurin did not have a pinkish colour, but had more orange nuance of the colour. The sausages that were supplemented with both monolaurin in the lowest concentration used, in this case of $0.36 \%$ and nitrite salt, in the two times lower concentration than when it was used as a sole additive i.e the concentration of $0.6 \%$, showed to have about 5 times lower value for the total cell count than the additive free sausage, $33 \pm 5 \times 10^{7} \mathrm{cfu} / \mathrm{mL}$.

It was also very interesting to check if the increase in the concentration of monolaurin had some strong antimicrobial effect when applied as a sole additive in this kind of sausages (Table 2).

Table 2. The effect of the monolaurin concentration on the growth inhibition of $B$. subtilis D-TMF in the sausages packed in natural pork casings. The sausages were packed in natural casings and contained only monolaurin as the food additive.

\begin{tabular}{ccc}
\hline Monolaurin added $^{\mathrm{a}}$ & Total cell count $^{\mathrm{b}}$ & Growth inhibition $^{\mathrm{c}}$ \\
\hline Control (additive free) & $1500 \pm 10$ & \\
90 & $710 \pm 10$ & 52.66 \\
180 & $10 \pm 1$ & 99.33 \\
720 & $6 \pm 1$ & 99.60 \\
\hline
\end{tabular}

a - $\mathrm{mg}$ monolaurin per $25 \mathrm{~g}$ sausage

b - number of colony forming units (cfu) calculated as 107 cfu per g sample c - $(\%)$

From the results presented in Table 2, it can be noticed that although the concentration of monolaurin was increased 4 times, from $180 \mathrm{mg}$ per 25 grams to $720 \mathrm{mg}$ per 25 grams sausage, the antibacterial activity of the additive was in the same order of magnitude i.e. the minimal inhibitory concentration was already reached. This means that after the minimal inhibitory concentration of the antimicrobial additive is reached, there is no need for further increase of the concentration. The sensory characteristic-the colour of the meat batter containing 180 and $360 \mathrm{mg}$ monolaurin, showed that both products had the acceptable orange-red colour (Figure 4).

Determination of the minimal bactericidal concentration (MBC) of monolaurin

The antimicrobial effect of monolaurin towards the bacterium $B$. subtilis D-TMF was investigated also in vitro by using the agar plate method. Nutritive agar plates with and without monolaurin were used for this purpose. It was obvious that monolaurin had a strong inhibitory effect to the growth of the bacterium. It seemed that the presence of monolaurin in the agar medium inhibited the growth of the bacterium, so the morphology of the grown cells differed a lot from the morphology of the healthy bacteria. The minimal bactericidal concentration of monolaurin was determined according to the procedure described in the experimental section. The results showed that monolaurin had a very strong antibacterial effect, and its minimal bactericidal concentration was $400 \mathrm{mg} / \mathrm{L}$. Several researchers, among which Kabara and Marshall, [14] claimed that monolaurin as an natural antimicrobial agent is characterised with the antimicrobial activity not only in vitro, but that its strong antimicrobial effect continues after its consumption in the human organism, and in this way it strengthens the immune system of the body. Thus, these kinds of food products that contain biologically active agents are considered as nutraceuticals, i.e. functional food products.

\section{Colour measurement}

Colour is an important parameter for the appearance of the product and has a high influence on the consumer's choice. The colour parameters $L^{*}, a^{*}, b^{*}$ and total changes of colour $\Delta \mathrm{E}$ of uncured and cured sausages are given in Table 2. According to the schema (Table 1), the sample number 6 was additive free and was taken as control when calculating the changes of the colour. The most important colour parameter for cured sausages is the $a^{*}$ value, since its positive values represent the red colour.

The results proved that by adding nitrite salt, the colour of the meat changed into pink. However, the increase of the concentration from $0.1 \%$ to $1.2 \%$ of this potentially harmful salt based on a total mass of the sausage does not affect the colour significantly. The pink nuance was more intense for only $19 \%$. By using monolaurin as a sole additive, the desired pink nuance could not be obtained. Instead, orange nuances are visible expressed by the $b^{*}$ value. Less total changes in the colour were noticeable in the samples $1,7,8$ and 9 where the only additive used was monolaurin.

Nevertheless, the acceptable visual appearance could be achieved by using the combination of the decreased concentration of nitrite salt and monolaurin as 
in the sample $2\left(0.72 \% \mathrm{ML}\right.$ and $\left.0.1 \% \mathrm{NaNO}_{2}\right)$. The $\mathrm{a}^{*}$ value was 12.46 , and the total colour change was 6.81

(Table 3).

Table 3. Colour measurements of raw and cured sausages with different concentrations of additives

\begin{tabular}{|c|c|c|c|c|}
\hline & $\mathrm{L}^{*}$ & $a^{*}$ & $b^{*}$ & $\Delta \mathrm{E}$ \\
\hline & \multicolumn{4}{|c|}{ raw sausages } \\
\hline 1 & $22.15 \pm 1.42^{\mathrm{a}}$ & $10.74 \pm 0.82^{\mathrm{a}}$ & $925 \pm 0.71^{\mathrm{a}}$ & $7.94 \pm 0.24^{\mathrm{a}}$ \\
\hline 2 & $17.01 \pm 3.15^{d}$ & $6.28 \pm 0.23^{\mathrm{a}}$ & $6.42 \pm 0.84^{\mathrm{a}}$ & $7.12 \pm 0.21^{\mathrm{a}}$ \\
\hline 3 & $19.62 \pm 2.37^{c}$ & $5.46 \pm 0.69^{\mathrm{a}}$ & $5.59 \pm 0.53^{\mathrm{a}}$ & $9.18 \pm 0.28^{\mathrm{a}}$ \\
\hline 4 & $14.34 \pm 1.51^{b}$ & $5.60 \pm 0.68^{\mathrm{a}}$ & $5.30 \pm 1.60^{b}$ & $7.68 \pm 0.23^{a}$ \\
\hline 5 (control) & $14.65 \pm 1.77^{b}$ & $12.87 \pm 1.72^{b}$ & $7.76 \pm 0.67^{\mathrm{a}}$ & $8.88 \pm 0.00^{\mathrm{a}}$ \\
\hline 6 & $17.54 \pm 2.75^{c}$ & $4.91 \pm 0.40^{\mathrm{a}}$ & $4.19 \pm 1.54^{b}$ & $9.19 \pm 0.28^{\mathrm{a}}$ \\
\hline 7 & $16.55 \pm 2.31^{c}$ & $5.08 \pm 0.56^{\mathrm{a}}$ & $5.70 \pm 1.09^{b}$ & $8.28 \pm 0.25^{\mathrm{a}}$ \\
\hline 8 & $17.97 \pm 1.99^{b}$ & $8.32 \pm 1.18^{b}$ & $6.35 \pm 1.52^{b}$ & $5.81 \pm 0.17^{\mathrm{a}}$ \\
\hline 9 & $19.05 \pm 1.51^{b}$ & $9.48 \pm 1.08^{b}$ & $6.64 \pm 0.49^{\mathrm{a}}$ & $5.67 \pm 0.17^{\mathrm{a}}$ \\
\hline 10 & $16.14 \pm 1.42^{b}$ & $4.44 \pm 0.84^{\mathrm{a}}$ & $4.42 \pm 1.05^{b}$ & $9.19 \pm 0.28^{\mathrm{a}}$ \\
\hline \multirow[t]{2}{*}{11} & $12.09 \pm 1.97^{b}$ & $6.57 \pm 0.18^{\mathrm{a}}$ & $3.47 \pm 2.15$ & $8.04 \pm 0.24^{\mathrm{a}}$ \\
\hline & \multicolumn{4}{|c|}{ cured sausages } \\
\hline 1 & $19.27 \pm 2.11^{c}$ & $6.55 \pm 0.68^{\mathrm{a}}$ & $11.00 \pm 1.60^{b}$ & $2.08 \pm 0.06^{\mathrm{a}}$ \\
\hline 2 & $18.67 \pm 3.91^{d}$ & $12.46 \pm 0.50^{\mathrm{a}}$ & $8.48 \pm 1.02^{b}$ & $6.81 \pm 0.20^{\mathrm{a}}$ \\
\hline 3 & $26.23 \pm 1.30^{b}$ & $12.35 \pm 2.04^{c}$ & $9.13 \pm 0.48^{\mathrm{a}}$ & $7.67 \pm 0.23^{\mathrm{a}}$ \\
\hline 4 & $24.43 \pm 1.55^{b}$ & $14.69 \pm 1.20^{b}$ & $11.16 \pm 0.68^{\mathrm{a}}$ & $8.50 \pm 0.26^{\mathrm{a}}$ \\
\hline 5 (control) & $21.35 \pm 4.00^{d}$ & $6.76 \pm 0.57^{\mathrm{a}}$ & $11.08 \pm 1.12^{b}$ & $0.00 \pm 0.00^{\mathrm{a}}$ \\
\hline 6 & $24.58 \pm 3.31^{d}$ & $15.40 \pm 0.98^{\mathrm{a}}$ & $13.53 \pm 1.07^{b}$ & $4.69 \pm 0.14^{\mathrm{a}}$ \\
\hline 7 & $23.21 \pm 3.31^{d}$ & $9.36 \pm 2.88^{c}$ & $10.97 \pm 2.23$ & $3.20 \pm 0.10^{\mathrm{a}}$ \\
\hline 8 & $19.25 \pm 3.17^{d}$ & $5.83 \pm 0.34^{\mathrm{a}}$ & $7.97 \pm 1.04^{b}$ & $3.86 \pm 0.12^{a}$ \\
\hline 9 & $22.01 \pm 1.87^{b}$ & $9.10 \pm 1.74^{b}$ & $8.23 \pm 0.91^{\mathrm{a}}$ & $3.74 \pm 0.11^{\mathrm{a}}$ \\
\hline 10 & $24.00 \pm 4.53^{d}$ & $8.47 \pm 2.02^{b}$ & $14.55 \pm 1.80^{b}$ & $4.69 \pm 0.14^{\mathrm{a}}$ \\
\hline 11 & $26.96 \pm 2.44^{c}$ & $9.30 \pm 0.51^{\mathrm{a}}$ & $8.39 \pm 0.47^{a}$ & $6.72 \pm 0.20^{\mathrm{a}}$ \\
\hline
\end{tabular}

*Average values and standard deviations are reported

The values with a different letter in a given column are significantly different $(p<0.05)$

\section{Conclusions}

The possibility for the cleaner production of cured meat products containing lower amounts of potentially toxic nitrite salts, or nitrite free (organic) was investigated. The results showed that the natural antimicrobial additive, monolaurin, had superior performances as the antibacterial agent when its antibacterial activity was investigated on the bacterium Bacillus subtilis D-TMF as a test microorganism. The application of monolaurin resulted in producing cured meat products with both acceptable colour and microbiological safety, when this FDA approved food additive was used separately or in the combination with table salt and decreased amounts of nitrite salt. The colour parameters $L^{*}, a^{*}, b^{*}$ and total changes of colour $\Delta \mathrm{E}$ of uncured and cured sausages were determined and they showed that the increase of the concentration from $0.1 \%$ to $1.2 \%$ of the nitrite salt does not affect the colour significantly and that the acceptable visual appearance could be achieved by using the combination of a decreased concentration of nitrite salt and monolaurin (0.72\% $\mathrm{ML}$ and $\left.0.1 \% \mathrm{NaNO}_{2}\right)$.

\section{Acknowledgments}

The authors would like to thank the Faculty of Technology and Metallurgy, University of Ss. „Cyril and Methodius“, Skopje, the Republic of Macedonia, for every kind of support given during the research that is now part of this paper. The support given from Mr Zarko Mladenoski is also gratefully acknowledged.

\section{References}

[1] J. T. Keeton Formed and emulsified products, in: A. R. Sams Ed. Poultry meat processing, CRC Press, USA, 2001, pp. 195-227.

[2] www.epa.gov/teach (US EPA TEACH (2007): A report of the Environmental Protection Agency of USA on the toxicity and exposure assessment for children's health (TEACH))

[3] F. Toldra, M. Reig. Sausages, in: Y. H. Hui Ed. Food product manufacturing, John Wiley \& Sons, Inc., Hoboken, NJ, USA, 2007, pp. 251-264.

[4] J. G. Sebranek, J. N. Bacus. Cured meat products without direct addition of nitrate or nitrite: what are the issues? Meat Science, 77 (2007) 136-147.

[5] J. J. Sindelar, Curing. Natural and organic cured meat products in the United States, in: D.Carrick, M. Dikeman, 
Eds. Encyclopaedia of Meat Sciences (Second Edition), Elsevier Ltd., San Diego, USA, 2014, pp. 430-435.

[6] R. B. Tompkin. Nitrite in: P. M. Davidson, J. N. Sofos, A. L. Branen. Antimicronials in Food, CRC Press, USA, 2005, pp. 169-237.

[7] A. S. Yadav, R. P. Singh. Natural preservatives in poultry meat products. Natural Product Raiance, 3 (2004) 300303.

[8] H.R. Cheisari, V.R. Ranjbar. Antioxidative and antimicrobial effects of garlic in ground camel meat. Turkish Journal of Veterinary \& Animal Sciense, 36 (2012) 13-20.

[9] P. D. Serrone, M. Nikoletti, Antimicrobial activity of a neem cake extract in a broth model meat system. International Journal of Envionmental Research and Public Health, 10 (2013) 3282-3295.

[10] T. Aymerich, A . Picouet, J. M. Monfert, Decontamination technologies for meat products. Meat Science, 78 (2008) 114-129.

[11] G. Pardo, J. Zufia, Life cycle assessment of foodpreservation technologies. Journal of Cleaner Production, 28 (2012) 198-207.

[12] M. W. Siddiqui, I. Chakraborty, J. F. Ayala-Zavala, R. S. Dhua, Advances in minimal processing of fruits and vegetables. Journal of Scientifc \& Industrial Research, 70 (2011) 823-834.

[13] E. Mbandi, M. Brywig, L. A. Shelef, Antilisterial effects of free fatty acids and monolaurin in beef emulsions and hot dogs. Food Microbiology, 21 (2004) 815-818.

[14] J. J. Kabara, D. L. Marshall, Medium-Chain Fatty Acids and Esters, in: P.M. Davidson, J.N. Sofos, A.L. Branen, Eds. Antimicrobials in Food, CRC Press, Taylor \& Francis Group, Boca Raton, USA, 2005, pp. 327-361.

[15] J Ružička, K. Velclova, R. Janiš, J. Krejči. Antimicrobial effects of 1-monoacylglycerols prepared by catalytic reaction of glycidol with fatty acids. European Food Research Technology, 217 (2003) 329-331.

[16] Z. Rihakova, V. Filip, M. Plockova, J. Šmidrkal, R. Červenkova, Inhibition of Aspergillus niger DMF 0801 by monoacyl-glycerols prepared from coconut oil. Czech Journal of Food Science, 20 (2002) 48-52.

[17] E. Skrivanova, M., Marounek, V. Benda, P. Brezina,
Susceptibility of Escherichia coli, Salmonella sp. and Clostridium perfringens to organic acids and monolaurin. Veterinary Medicine, 51 (2006) 81-88.

[18] M. K. M. Nair, J. Joy, K. S. Venkitanarayanan. Inactivation of Enterobacter sakazakii in reconstituted infant formula by monocaprylin. Journal of Food Protection, 67 (2004) 2815-2819.

[19] www.efsa.europa.eu (EFSA, 2005. EFSA (European Food Safety Authority) Journal 2005: Opinion of the Scientific Panel on Biological Hazards on the request from the Commission related to Clostridium spp. in foodstuffs.

[20] www.cdc.gov/ncezid/2010-report (NCEZID, (2010). Division of Foodborne, Waterborne and Environmentally Diseases, USA.

[21] R. Villota, J. G. Hawkes, Reaction kinetics in food systems in: D. Heldman, D. Lund. Handbook of Food Engineering, 2nd edition, CRC Press Taylor and Francis Group, 2006, pp. $125-287$.

[22] L. N. Christiansen, R. W. Johnston, D. A. Kautter, J. W. Howard, W. J. Aunan, Effect of nitrite and nitrate on toxin production by Clostridium botulinum and on nitrosamine formation in perishable canned comminuted cured meat, Applied Microbiology, 25 (1973) 357-362.

[23] R. Cammack, C. L. Joannou, X. Y. Cui, C. T. Martinez, S. R. Maraj, M. N. Hughes, Nitrite and nitrosyl compounds in food preservation, Biochimica et Biophysica Acta, 1411 (1999) 475-488.

[24] R. L. Santarelli, F. Pierre, D. E. Corpet, Processed meat and colorectal cancer: a review of epidemiologic and experimental evidence, Nutrition and cancer, 60 (2008) 131-144.

[25] D. I. Batovska, I. T. Todorova, I. V. Tsvetkova, H. M. Najdenski, Antimicrobial study of the medium chain fatty acids and their 1-monoglycerides: individual effects and synergistic relationships. Polish Journal of Microbiology, 58 (2009) 43-47.

[26] M. A. Zare, S. M. R., Rohani, M. Raeisi, S. H. J. Hosseini, M.Hashemi, Antibacterial effects of monolaurin, sorbic acid and potassium sorbate on Staphylococcus aureus and Escherichia coli. Journal of Food Quality and Hazards Control, 1 (2014) 52-55.

\section{Izvod}

\section{UTICAJ MONOLAURINA NA BOJU I MIKROBIOLOŠKU STABILNOST KOBASICA SA MALIM KONCENTRACIJAMA NITRITA}

Irina Mladenoska, Misela Temkov, Darko Dimitrovski

Departman za Prehrambenu tehnologiju i biotehnologiju, Tehnološko-metalurški fakultet, Univerzitet "Sveti Ćiril i Metodije”, Skopje, Makedonija

Cilj ovog rada je analiza mogućnosti razvoja novih salamurenih proizvoda od mesa sa smanjenim sadržajem nitrita, nepromenjenim senzornim karakteristikama i produženim rokom trajanja. U tu svrhu, analizirana je mogućnost potpune zamene ili smanjenja količine sadržaja nitrita upotrebom netoksičnih aditiva. $U$ radu je izvršena procena uticaja različitih receptura na senzorne karakteristike i mikrobiološku stabilnost proizvoda od mesa. Rezultati su pokazali da se čak i pri veoma malim koncentracijama nitrita, ali u prisustvu monolaurina, može postići željena boja nadeva. Zamena polovine količine nitritne soli $(0,2 \%)$ sa $0,72 \%$ monolaurina pri proizvodnji kobasica punjenih u kolagenski omotač omogućava dobijanje mikrobiološki stabilnog proizvoda sa dobrim senzornim karakteristikama. Tako pripremljen proizvod ima 21 put manju vrednost ukupnog broja ćelija bakterije Bacillus subtilis $D-T M F$ u poređenju sa proizvodom koji je pripremljen samo sa dodatkom nitritne soli.
(ORIGINALNI NAUČNI RAD) UDK 637.523.05:664.9

Ključne reči: salamureni proizvodi od mesa, smanjen sadržaj nitrita, aditivi u hrani, monolaurin 